\title{
Study of Covid 19 Occurrence in Relation to Masks and Hand Sanitizers Use
}

\author{
Anwar Mallongi ${ }^{1}$, Agus Bintara Birawida ${ }^{2}$, Noer Bahri Noor ${ }^{3}$, \\ M. Fais Satrianegara ${ }^{3}$, Wa Ode Fifin Annur ${ }^{4}$, Fatmawati ${ }^{5}$ \\ ${ }^{1,2}$ Lecturers of Departement of Environmental Health, Public Health Hasanuddin University, ${ }^{3}$ Senior Lecturer \\ of Department of Hospital Administration, Hasanuddin University, Makassar, Indonesia, ${ }^{4}$ Senior Lecturer of \\ Faculty of Medicine and Health Sciences, Alauddin State Islamic University, of Makassar, Indonesia, ${ }^{4}$ Student of \\ Departement of Environmental Health, Public Health Hasanuddin University, ${ }^{5}$ Lecturer, Department of Nutrition, \\ Health Polytechnic of Health Ministry, Kendari, Indonesia
}

\begin{abstract}
Covid-19 is an infectious disease that has the potential to cause a public health emergency. Therefore, preventive measures against these types of infectious diseases must be carried out as soon as possible. Indonesia as a rule of law, therefore the prevention of these types of infectious diseases must be established in a rule or regulation. The purpose of this literature review is to describe an intervention regarding the use of masks and handsanitizers against the incidence of Covid 19. The database searches used include ProQuest, SciVerse Science Direct, Scopus, Pubmed, Cohcrane library, Springer and Sci-hub. Keywords used in the search for articles were mask, hand sanitizer, preventive, COVID-19. There are 18 journal articles obtained through objective analysis, topic suitability, research method used, sample size, research ethics, the results of each article, and the limitations that occur. There have been effective results in implementing the distribution of covid 19 events related to the use of masks and hand sanitizers. There have been effective results in using masks and hand sanitizers against the incidence of covid-19
\end{abstract}

Keywords: Covid 19, masks, hand sanitazer.

\section{Introduction}

The Indonesian government has declared a disaster emergency status related to this virus pandemic. The government made a policy to implement physical distancing to decide the spread of covid 19. People are advised not to make direct contact with other people, avoid mass gatherings. Work, study and worship activities are carried out at home ${ }^{1}$. Current information indicates that the two main modes of transmission of the COVID-19 virus are respiratory droplets and contact. Respiratory sprays are generated when a person coughs

\footnotetext{
Corresponding Author: Anwar Mallongi

Lecturers of Departement of Environmental Health, Public Health Hasanuddin University

e-mail: anwar_envi@yahoo.com
}

or sneezes. Anyone who is in close contact (within a radius of $1 \mathrm{~m}$ ) with a person who shows symptoms of respiratory distress (coughing, sneezing) is at risk of exposure to respiratory tract splashes that could possibly cause infection (infectious). Splashes can also fall onto surfaces on which the virus remains active; therefore, the immediate environment of an infected person can be a source of transmission (contact transmission). ${ }^{2,3}$

The mechanism that occurs is by capturing particles or aerosols from the air with a filtering or absorption method, so that the air that passes through the mask is clean from particulates ${ }^{4}$. Prevention of transmission of Covid19 to the community is carried out with various efforts. Based on the health protocol issued by the WHO, the government instructs the public to always wash their hands with soap in running water, and always wear a mask when outside the home. Why wear a mask? A recent study by the Standing Commission for Infectious Diseases and 21st Century Threats in the United States 
said that COVID19 can be transmitted through normal conversation and breathing with an exposed person. Based on the research, the Ministry of Health (2020: 2) explained that this disease can be spread through small droplets from the nose or mouth when coughing or sneezing. The droplet then falls on the surrounding object.

Masks are necessary for everyone so that they do not spread the virus to each other because this virus is transmitted between humans and humans and spreads very quickly. A high chance of transmission can occur when exposed people interact with healthy people and healthy people interact with other people and so on. Seeing the current tense situation, namely the Covid-19 pandemic that has occurred throughout the world, it is necessary to make efforts to prevent the spread of the corona virus. Thus the Community Service team felt the need to carry out activities to break the distribution chain of Covid-19 by distributing free masks and hand sanitizers to the Manggarai community in the Puni Ruteng market, Manggarai Regency.

Hand-saitizer is a product in the form of a gel that contains an antiseptic as a hand sanitizer which, if used, does not need to be rinsed with water. ${ }^{8}$ Using it is very effective at killing transient and resident flora compared to using water, using ordinary soap or antiseptic soap. FDA) that hand-sanitizers can kill germs in less than 30 seconds $^{5}$. The purpose of this activity is to make the public aware of the importance of health in this pandemic situation, always wash their hands with soap, use a hand sanitizer and wear a mask to stop transmission of the virus to others.

\section{Materials and Method}

The method used in this review literature uses a comprehensive strategy, such as searching for articles in research journal databases, searching through the internet, reviewing articles. The database searches used included ProQuest, SciVerse ScienceDirect, Scopus, Pubmed, Cohcrane library, Springer and Sci-hub. The keywords used in the search for the article were the study of covid 19, health promotion, use of masks, use of handsanitizers and Covid 19. There were 18 journal articles and were analyzed through objective analysis, topic suitability, research method used, sample size, research ethics, results. of each article, as well as the limitations that occur.

\section{Results}

Table 1. Distribution of Covid 19 occurrence base on the reviewed articles

\begin{tabular}{|c|c|c|c|c|}
\hline Authors & Title & Sample & Method & Output \\
\hline $\begin{array}{l}\text { (Chi-Chung, } \\
2020)^{6}\end{array}$ & $\begin{array}{l}\text { The role of community- } \\
\text { wide wearing of face } \\
\text { mask for control of } \\
\text { coronavirus disease } 2019 \\
\text { (COVID-19) epidemic } \\
\text { due to SARS-CoV-2 }\end{array}$ & 100 & $\begin{array}{l}\text { Epidemiology } \\
\text { Analysis }\end{array}$ & $\begin{array}{l}\text { In the first } 100 \text { days ( } 31 \text { December } 2019 \text { to } 8 \text { April } \\
2020), 961 \text { COVID-19 patients were diagnosed. nosed } \\
\text { in HKSAR. The incidence of COVID-19 in HKSAR } \\
(129.0 \text { per million population) was significantly } \\
\text { lower }(p<0.001) \text { than Spain }(2983.2) \text {, Italy }(2250.8) \text {, } \\
\text { Germany }(1241.5) \text {, France }(1151.6) \text { ), USA }(1102.8) \text {, } \\
\text { UK }(831.5) \text {, Singapore }(259.8) \text {, and South Korea } \\
(200.5) \text {. }\end{array}$ \\
\hline (E, et al., 2020) & $\begin{array}{l}\text { To mask or not to mask: } \\
\text { Modeling the potential } \\
\text { for face mask use by the } \\
\text { general public to curtail } \\
\text { the COVID-19 pandemic }\end{array}$ & & $\begin{array}{l}\text { Eksperimental } \\
\text { study }\end{array}$ & $\begin{array}{l}\text { Our results suggest the use of face masks by the } \\
\text { general public is potential of high value in limiting } \\
\text { community transmission and the burden of the } \\
\text { pandemic. }\end{array}$ \\
\hline $\begin{array}{l}\text { (Wang, Pan, } \\
\text { Tang, \& Shi, } \\
2020)^{7}\end{array}$ & $\begin{array}{l}\text { Mask use during } \\
\text { COVID-19: A risk } \\
\text { adjusted strategy }\end{array}$ & & $\begin{array}{l}\text { Efektivity } \\
\text { Study }\end{array}$ & $\begin{array}{l}\text { This study 1) describes the transmission route of } \\
\text { Coronavirus } 2 \text { Severe Acute Respiratory Syndrome } \\
\text { (SARS-CoV-2); 2) addresses the controversy } \\
\text { surrounding masks from the perspective of attitudes, } \\
\text { effectiveness, and the necessity of wearing masks } \\
\text { with evidence that the use of masks will effectively } \\
\text { stop transmission of infectious diseases both in the } \\
\text { hospital setting and in the setting community; and } \\
\text { 3) recommends that people wear masks during the } \\
\text { COVID-pandemic according to the local context. }\end{array}$ \\
\hline
\end{tabular}


Based on the results of articles and journals that were collected and the author's analysis, it was found that there was a relationship between the use of masks and hand sanitizers to the Covid 19 incident. The behavior of wearing a mask and handsanitizer when doing activities is an effort in the form of preventing the occurrence of covid transmission 19.

Table 2. The occurrence of Covid-19 base on the lierature review

\begin{tabular}{|c|c|c|c|c|}
\hline Authors & Title & Sample & Method & Output \\
\hline $\begin{array}{l}\text { (Lyu \& Wehby, } \\
2020)^{8}\end{array}$ & $\begin{array}{l}\text { Community Use Of Face } \\
\text { Masks } \\
\text { And COVID-19: Evidence } \\
\text { From } \\
\text { A Natural Experiment Of } \\
\text { State } \\
\text { Mandates In The US }\end{array}$ & & $\begin{array}{l}\text { Experience } \\
\text { difference design }\end{array}$ & $\begin{array}{l}\text { There was a significant decrease in daily } \\
\text { COVID- } 19 \text { growth rates after mandating face } \\
\text { coverings in public, with the effect increasing } \\
\text { over time after the order sign. Specifically, } \\
\text { daily case rates fell by } 0.9,1.1,1.4,1.7 \text {, and } \\
2.0 \text { percentage-points of age in } 1-5,6-10 \text {, } \\
11-15 \text {, and } 16-20 \text {, and } 21+\text { days after signing, } \\
\text { respectively. }\end{array}$ \\
\hline $\begin{array}{l}\text { (Saadat et al., } \\
2020)^{9}\end{array}$ & $\begin{array}{l}\text { Environmental perspective } \\
\text { of covid-19 https:// } \\
\text { doi.org/10.1016/j. } \\
\text { scitotenv. } 2020.138870\end{array}$ & & & $\begin{array}{l}\text { Many think that there is an upside; that the } \\
\text { spread of the virus has reduced air and water } \\
\text { pollution and perhaps even saved lives in this } \\
\text { process. Public action to humiliate people } \\
\text { Transmission of COVID-19 to people needed } \\
\text { to control the flow Epi-demic has also changed } \\
\text { people's lifestyles; causing extensive job losses } \\
\text { and threatening the survival of millions, as } \\
\text { businesses close down to control the spread of } \\
\text { the virus. }\end{array}$ \\
\hline $\begin{array}{l}\text { (Nuraeni, } \\
\text { Malinti, \& } \\
\text { Elon3, 2020) }\end{array}$ & $\begin{array}{l}\text { Preparedness of youth in } \\
\text { the face of the covid-19 } \\
\text { outbreak }\end{array}$ & 105 & Deskriptive Study & $\begin{array}{l}\text { Research has reflected a sense of adolescent } \\
\text { care to prevent and stop the spread of covid-19. } \\
\text { Efforts that can be made to deal with Covid } \\
19 \text { are to continue to do physical distancing, } \\
\text { diligently wash their hands, use masks } \\
\text { when leaving the house, and carry out their } \\
\text { obligations as students to study at home online }\end{array}$ \\
\hline $\begin{array}{l}\text { (Sii, Filomena, } \\
\text { Effrem, } \\
\text { Klaudia, \& } \\
\text { Nesi, 2020) }\end{array}$ & $\begin{array}{l}\text { A form of concern for } \\
\text { fighting Covid- } 19 \text { through } \\
\text { the distribution of } 5,000 \\
\text { masks and hand sanitizers } \\
\text { to the public in the Puni } \\
\text { Ruteng - Manggarai market }\end{array}$ & & $\begin{array}{l}\text { Distribution } \\
\text { of masks to all } \\
\text { people regardless } \\
\text { of age, and hand } \\
\text { sanitizers are } \\
\text { only distributed } \\
\text { specifically to } \\
\text { travel drivers }\end{array}$ & $\begin{array}{l}\text { As a result, this activity was able to provide } \\
\text { awareness to the public about the importance of } \\
\text { maintaining health and overcoming the spread } \\
\text { of Covid-19 in Manggarai Regency in general. }\end{array}$ \\
\hline $\begin{array}{l}\text { (Meri, Khusnul, } \\
\text { Suhartati, } \\
\text { Mardiana, } \\
\& \text { Nurpalah, } \\
2020)^{15}\end{array}$ & $\begin{array}{l}\text { Community empowerment } \\
\text { in the use of hand sanitizers } \\
\text { and masks as a preventive } \\
\text { effort against Covid-19 }\end{array}$ & 100 & $\begin{array}{l}\text { Community } \\
\text { education }\end{array}$ & $\begin{array}{l}\text { The results obtained are that } 100 \text { target people } \\
\text { have received handsanitizers and } 200 \text { people } \\
\text { have received masks. Thus, the surrounding } \\
\text { community can finally use masks and supplies } \\
\text { of handsanitizer when leaving the house. }\end{array}$ \\
\hline$(\text { Ester, 2020) })^{16}$ & $\begin{array}{l}\text { The incidence of corona } \\
\text { virus disease } 2019 \text { is based } \\
\text { on population density and } \\
\text { altitude per sub-district }\end{array}$ & & $\begin{array}{l}\text { Journal of } \\
\text { Public Health } \\
\text { and comunity } \\
\text { Medicine }\end{array}$ & $\begin{array}{l}\text { The results of this study indicate that most } \\
\text { sub-districts in the city of Manado are in the } \\
\text { medium category for COVID 19, medium and } \\
\text { high for population density and medium for the } \\
\text { altitude category. }\end{array}$ \\
\hline $\begin{array}{l}\text { (Moudy \& } \\
\text { Adlia, 2020) }\end{array}$ & $\begin{array}{l}\text { Knowledge related to efforts } \\
\text { to prevent coronavirus } \\
\text { disease (covid-19) in } \\
\text { Indonesia }\end{array}$ & 1096 & $\begin{array}{l}\text { observasional } \\
\text { analitik dengan } \\
\text { desain cross- } \\
\text { sectional }\end{array}$ & $\begin{array}{l}\text { There is a significant relationship between } \\
\text { knowledge and attitude }(\mathrm{p}=0.000) \text { and } \\
\text { knowledge with individual actions }(\mathrm{p}=0.000) \text {. } \\
\text { Efforts to prevent COVID- } 19 \text { are influenced by } \\
\text { the knowledge of the Indonesian people. }\end{array}$ \\
\hline
\end{tabular}


Table 3. Distribution of Covid 19 occurrence base on the reviewed articles

\begin{tabular}{|c|c|c|c|c|}
\hline Authors & Title & Sample & Method & Output \\
\hline $\begin{array}{l}\text { (Theopilus, } \\
\text { Yogasara, Theresia, } \\
\& \text { Octavia, 2020) }\end{array}$ & $\begin{array}{l}\text { Risk analysis of personal } \\
\text { protective equipment } \\
\text { products Prevention of } \\
\text { covid-19 transmission } \\
\text { for informal workers in } \\
\text { Indonesia }\end{array}$ & $\begin{array}{l}15 \\
\text { aspect }\end{array}$ & $\begin{array}{l}\text { Failure Mode } \\
\text { and Effect } \\
\text { Analysis } \\
\text { (FMEA) }\end{array}$ & $\begin{array}{l}\text { The analysis results, obtained a total of } 10 \text { mask } \\
\text { risks, } 15 \text { face shield risks, and } 11 \text { glove risks that } \\
\text { need to be considered by informal workers as well } \\
\text { as PPE designers and producers. }\end{array}$ \\
\hline$(\text { Ester, 2020) })^{19}$ & $\begin{array}{l}\text { The incidence of corona } \\
\text { virus disease } 2019 \text { is based } \\
\text { on population density and } \\
\text { altitude per sub-district }\end{array}$ & & Observasional & $\begin{array}{l}\text { The results of this study indicate that most sub- } \\
\text { districts in the city of Manado are in the medium } \\
\text { category for COVID 19, medium and high for } \\
\text { population density and medium for the altitude } \\
\text { category. Furthermore, based on population } \\
\text { density, the higher the density, the higher the } \\
\text { incidence of COVID } 19 .\end{array}$ \\
\hline $\begin{array}{l}\text { (Pramita, Sholihah, } \\
\& \text { Atiqoh, 2020) }\end{array}$ & $\begin{array}{l}\text { The relationship between } \\
\text { public knowledge and } \\
\text { compliance with the use } \\
\text { of masks as an effort } \\
\text { to prevent Covid-19 in } \\
\text { ngronggah }\end{array}$ & 62 & $\begin{array}{l}\text { Quantitative } \\
\text { with cross } \\
\text { sectional } \\
\text { approach }\end{array}$ & $\begin{array}{l}\text { Based on the results of the Chi-Square test, the } \\
\text { significance of the independent variables, namely } \\
\text { public knowledge with the dependent variable } \\
\text { of compliance with the use of masks, is } 0.004 \text { (p } \\
<0.05 \text { ), so Ho is rejected and it is stated that there } \\
\text { is a relationship. }\end{array}$ \\
\hline $\begin{array}{l}\text { (Sukesih, Usmanb, } \\
\text { Budi,\& Nur, 2020) }\end{array}$ & $\begin{array}{l}\text { Knowledge and attitudes } \\
\text { of health students about } \\
\text { covid-19 prevention in } \\
\text { Indonesia }\end{array}$ & 444 & $\begin{array}{l}\text { Survey } \\
\text { analytic }\end{array}$ & $\begin{array}{l}\text { The results of the research on the knowledge } \\
\text { questionnaire were highest in the good category as } \\
\text { many as } 228(51.35 \%) \text { while the highest attitude } \\
\text { was in the good attitude category were } 206 \\
(46.39 \%) \text {. }\end{array}$ \\
\hline
\end{tabular}

\section{Discussions}

Some efforts are made by the government through the covid-19 control team and health team to reduce the risk of contracting the corona virus, among others; remind the public to maintain health by washing hands after making contact with anyone in flowing water, consuming vitamins that can increase endurance, quarantining people suspected of being infected with the corona virus, wearing masks when they are outside the home and in places -public places, maintain distance, and do not make direct contact with other people.

This is consistent with research conducted by WHO on influenza, influenza-like illness (influenza-like illness), and coronavirus in humans providing evidence that the use of medical masks can prevent the spread of splashes that can cause infection from an infected person to another. and possible environmental contamination from these splashes. Evidence that the use of medical masks by healthy people inside the home or by people who have contact with patients, or by people in large gatherings serves as a preventive function is limited.
Research by (Moudy \& Adlia, 2020) states that the correct use of masks is known by almost all respondents, namely masks are worn with a position to completely cover the nose, mouth and chin (96.6\%), and throw away the masks that have been used $(79,7 \%)$. More than half of the respondents know that if the mask is wet or dirty, it must be replaced immediately (75.1\%) and wash their hands after removing the mask (59.4\%). Only a small proportion of respondents chose the wrong option, namely touching the front surface of the mask while wearing it and taking it off $(14.1 \%)$, and using one disposable mask repeatedly $(13.5 \%)$.

Research by Rivai, Ayini S, Yesintha states that Hand sanitizer is a product that can clean hands that contain an antiseptic in the form of a gel which when used to wash hands no longer need to rinse with water. Alcoholbased products, which include almost all "disinfectant" products, contains a high percentage alcohol solution (usually $60-80 \%$ ethanol) and kills viruses in a similar way. But soap is better because it requires only a small amount of soapy water, which, by rubbing, covers the entire hand easily. ${ }^{22-28}$ 


\section{Conclusion}

The relationship between the use of masks and hand sanitizers to the incidence of Covid 19. Covid-19 is an infectious disease that has the potential to cause a public health emergency. Therefore, preventive measures against these types of infectious diseases must be carried out as soon as possible. Indonesia as a rule of law, therefore the prevention of these types of infectious diseases must be established in a rule or regulation. Prevention of transmission of Covid-19 in the community is carried out with various efforts. Based on the health protocol issued by the WHO, the government instructs the public to always wash their hands with soap in running water, and always wear a mask when outside the home. In addition, the use of handsanitizers that contain antiseptics as hand sanitizers, which if you do not need to be rinsed with water, are very effective in killing transient and resident flora compared to using water, using ordinary soap or antiseptic soap

Ethical Clearance: Taken from University ethical clearance committee

\section{Source of Funding: Self}

\section{Conflict of Interest: Nil.}

\section{References}

1. Ihsanuddin. okowi: Kerja dari Rumah, Belajar dari Rumah, Ibadah di Rumah Perlu Digencarkan Artikel ini telah tayang di Kompas.com dengan judul "Jokowi: Kerja dari Rumah, Belajar dari Rumah, Ibadah di Rumah Perlu Digencarkan", 2020 https://nasional.kompas.com/read/2020/09. Kompas.

2. World Health Organization. Anjuran mengenai penggunaan masker dalam konteks COVID-19 (diakses 11 September 2020)

3. WHO, Anjuran mengenai masker dalam konteks COVID-19: Panduan Sementara 6 April.2020. https://www.who.int/docs/defaultsource/ searo/indonesia/covid19/anjuranmengenaipenggunaan-masker-dalam-konteks-covid-19. pdf? sfvrsn=8a209b04_2

4. Moeljosoedarmo, Soeripto. Higiene Industri. Jakarta: Balai Penerbit FKUI Wikipedia, Kabupaten Muna. 2020

5. Rivai, M. N., Ayini, N. 1., \& Amelia, Y. M.. Perbedaan Efektivitas Hand-Sanitizer Dengan Cuci
Tangan Menggunakan Sabun Sebagai Bentuk (Vol. 2). Health Sciences and 2020; Research: 65-70.

6. Chi-Chung, V. C. The role of community-wide wearing of face mask for control of coronavirus disease (COVID-19) epidemic due to SARS-CoV-2 (Vol. 81). Journal of Infection: 2020; 107-114.

7. Wang, J., Pan, L., Tang, S., \& Shi, X. Mask use during COVID-19: A risk adjusted strategy. Environmental Pollution. 2020

8. Lyu, W., \& Wehby, G. L. Community Use Of Face Masks And COVID-19: Evidence From A Natural Experiment Of State Mandates In The US. HEALTH AFFAIRS, 2020; 39(8), 1-7.

9. Saadat, S., Rawtani, D., \& Mustansar, C. H. Environmental Perspective of Covid-19. Science of the Total Environment, 2020; 1-5.

10. Nuraeni, R. N., Malinti, E., \& Elon3, Y. Kesiapsiagaan remaja dalam menghadapi wabah covid-19 2020; (vol. 15). 111: Jurnal Ilmiah Kesehatan Diagnosis.

11. Dian, A. P. Gambaran Penggunaan Masker di Masa Pandemi Covid-19 Pada Masyarakat di Kabupaten Muna. Prosiding Seminar Nasional Problematika Sosial Pandemi Covid: 2020; 52-57.

12. Ratu, B., Anggraini, F. H., \& Susilawati, I. Covid-19 dan penyemprotan disinfektan pada warga bumi harapan permai (vol. 1). Jurnal Pengabdian Kepada Masyarakat Cahaya Mandalika: 2020; 45-48.

13. Telaumbanua, D. Urgensi Pembentukan Aturan Terkait Pencegahan Covid-19 di Indonesia (Vol. 12). Qalamuna - Jurnal Pendidikan, Sosial, dan Agama: 2020; 59-70.

14. Sii, P., Filomena, P. I., Effrem, Y. W., Klaudia, A. D., \& Nesi, A. Wujud Kepedulian Melawan Covid-19 Melalui Kegiatan Pembagian 5.000 Masker Dan Hand Sanitizer Kepada Masyarakat Di Pasar Puni Ruteng - Manggarai (Vol. 3). Available online at: 2020; 93-99.

15. Meri, M., Khusnul, K., Suhartati, R., Mardiana, U., \& Nurpalah, R. Pemberdayaan Masyarakat Dalam Penggunaan Hand Sanitiser Dan Masker Sebagai Upaya Preventif Terhadap Covid-19 (Vol. 2). Bantenese Jurnal Pengabdian Masyarakat: 2020; 20-33.

16. Ester, J. N. Kejadian Corona Virus Disease berdasarkan Kepadatan Penduduk dan Ketinggian Tempatper Wilayah Kecamatan(Vol. 1). Indonesian Journal of Public Health and Community Medicine: 
2020; 32-45.

17. Moudy, J., \& Adlia, R. S. Pengetahuan terkait Usaha Pencegahan Coronavirus Disease (COVID-19) di Indonesia (Vol. 4). Higeia Journal Of Public Health Research And Development: 2020; 303-346.

18. Theopilus, Y., Yogasara, T., Theresia, C., \& Octavia, J. R. Analisis Risiko Produk Alat Pelindung Diri (APD). Jurnal Rekayasa Sistem Industri, 2020; 9(2), 115-134.

19. Ester, J. N. Kejadian Corona Virus Disease 2019 berdasarkan Kepadatan Penduduk dan Ketinggian Tempat per Wilayah Kecamatan. Indonesian, 2020; 1(2), 23-45.

20. Pramita, D. S., Sholihah, N., \& Atiqoh. Hubungan Antara Pengetahuan Masyarakat Dengan Kepatuhan Penggunaan Masker Sebagai Upaya Pencegahan Penyakit Covid-19 Di Ngronggah. Jurnal Ilmiah Rekam Medis dan Informatika Kesehatan, 2020; 10(1), 52-55.

21. Sukesih, Usmanb, Budi, S., \& Nur, D. A. Pengetahuan Dan Sikap Mahasiswa Kesehatan Tentang Pencegahan Covid-19 Di Indonesia. Jurnal Ilmu Keperawatan dan Kebidanan, 2020; 11(2), 258-264.

22. Mallongi Anwar, et al., The Spatial Pattern and Risk Factors of Leprosy Occurrence in Barru, Indian
Jounal of Public Health Research \& development. 2018; 9(8), 1489-1494.

23. Rantetampang AL., Mallongi A. Risks Assessment Of Cadmium Through Aquatic Biota Consumption From Sentani Lake In Papua, Indonesia. 2013;2(6):2492-501.

25. Mallongi A., Herawaty. Assessment of mercury accumulation in dry deposition, surface soil and rice grain in Luwuk gold mine, Central Sulawesi. Res J Appl Sci. 2015;10(1):22-4.

26. Mallongi, A. P., Parkpian P., Pataranawat SC. Mercury distribution and its potential environmental and health risks in aquatic habitat at artisanal buladu gold mine in Gorontalo Province, Indonesia. Pak J Nutr. 2015;14:1010-25.

27. Budiani, N.N., Somoyani, N.K., Marhaeni, G.A., Erawati, L.P.S., Mallongi, A., Administration of tempehethanol extracts on prenatal until weaning inhibitory period the ovary follicles developing of little wistar rats. Indian Journal of Public Health Research and Development. 2018.

28. Anwar Mallongi, Ruslan La Ane and Agus Bintara Birawida. Ecological risks of contaminated lead and the potential health risks among school children in Makassar coastal area, Indonesia. J. Environ. Sci. Technol., 2017; 10: 283-289. 